\title{
PRESENCE IN CONTEMPORARY RELIGIOUS ART GRAHAM SUTHERLAND AND ANTONY GORMLEY
}

\author{
WESSEL STOKER*
}

Free University, Amsterdam

\begin{abstract}
This article analyses the topic of presence in modern and contemporary religious art by means of the work of two artists. Graham Sutherland's Christ in Glory (1951-1962) will be compared to the Buddhism-inspired works of Antony Gormley. Sutherlands Christ in Glory is intended to show Christ's presence to the involved observer: the invisible Christ can become present through interaction with Christ in Glory in the same way that Christ becomes present through prayer. Viewed in connection with other works by Gormley, Land, Sea, and Air II (1982) is intended to show presence to the viewer, the body as presence. This concerns an attitude of quiet concentration and awareness in connection with the 'elemental' world. Theologically speaking, the difference between Christ in Glory and Gormley's works is as follows: the Christian tradition views the human being as a creation of God. He or she lives in his or her presence only in dependence on God. For Gormley, it has to do with a presence without God the creator. The human being is present as body and awareness in a world in which everything is uncertain. There is an unmistakable difference in their views of presence, but that does not mean, as we will see, that Gormley's work cannot be fruitful for the Christian religion. Gormley's Sound II in the crypt of Winchester Cathedral points the involved observer to the importance of the renewal of life after baptism through meditation as an important part of Christian spirituality.
\end{abstract}

KEYWORDS: art, religion, presence in art, Graham Sutherland, Antony Gormley

Is art that shows religious presence at all possible in a secular culture? There are many examples of such religious art. Salvador Dali's Christ of Saint John of the Cross (1951) is a popular work: it shows the great Christ figure on the cross hovering above the earth, above Port Lligat in Spain and represents the words of Jesus at the conclusion of Matthew's gospel: 'And behold I am with you, even unto the end of the age.' Another example is Christ in Glory (1952) by the English artist Graham Sutherland. This work is a large tapestry that hangs behind the altar in the Coventry Cathedral that depicts the exalted Christ. His presentation of Christ is derived from the vision of John in which he sees Christ seated on a throne and, together with

* WESSEL STOKER (PhD 1980, Free University, Amsterdam) is professor emeritus of Aesthetics at Free University, Amsterdam. Email: wesselstoker@hetnet.nl. 
God the Father, actively engaged in bringing about the Kingdom of peace and righteousness (Revelation 4). For many, Sutherland's Christ in Glory shows the exalted Christ as continuing to be involved in saving the world.

Presence is also important in art inspired by Buddhism and Hinduism. The work of Anish Kapoor (1954) is an example of religious art as presence. His works show the holy as presence. Kapoor views any museum in which his work has been exhibited as a temple (Kaiser 2013: 109-119). The contemporary English sculptor Antony Gormley is inspired by Buddhism and makes presence central in his sculptures. His human-shaped sculpturesoften moulds of his own body-are displayed in public places in the city, the countryside, at the sea, or in museums.

These examples of presence in art do not undo the fact that, according to some, the idea of presence in art is under pressure in contemporary Western culture. The German-born American literary theorist Hans Ulrich Gumbrecht criticises a view of art that one-sidedly directs attention to meaning of an image (Gumbrecht 2004: 57). This does not do justice to the image in its materiality, in its presence. A hermeneutical-cognitive approach to art suppresses the materiality of a work and thus also its character as presence. Presence in art is under pressure in another way as well. The presence of what cannot be empirically observed, like the invisible God of the Bible, encounters little understanding in the Western view of the image that is directed at what is visible. The French philosopher and Christian theologian (member of the Académie française) Jean-Luc Marion criticises this view insofar as it cuts itself off from the invisible and thus also from the possible presence of God via the sacred portrait, the icon (Marion 2004).

In this case study, I will examine the topic of presence in modern and contemporary religious art by means of the work of two artists. I will compare Graham Sutherland's Christ in Glory (1951-1962) to the Buddhisminspired works of Antony Gormley. There is a unmistakable difference in their views of presence, but that does not mean, as we will see, that Gormley's work cannot be fruitful for the Christian religion. Sutherland's and Gormley's work are significant-each in its own way-for the discussion on presence in the philosophical approach to art in Gumbrecht and in the theological approach to art in Marion.

\section{Presence in the Work of Antony Gormley}

Antony Gormley (1950) lives and works in London and was the recipient of the Turner Prize in 1994. The human figure is central to his sculptures, but he gives an entirely different form to the human figure than found in the Western history of sculpture. That has to do with Gormley's religious view of art. For him, art comes from the same source as religion: searching for the existential meaning of human existence (Gormley 1987: 120). His art is 
an alternative to the restlessness of the human being who travels everywhere and is not at home anywhere (Gormley 1996b: 154). His art shows that the human being is rooted in a place and that presence is essential. In this context, Gormley refers to the topic of 'presence' in art as discussed by the German philosopher Heidegger. He cites the latter's The Origin of the Work of Art on the 'presence of the God':

A building, a Greek temple, portrays nothing. It simple stands there in het middle of the rock cleft valley. The building encloses the figure of the God and, in this concealment, lets it stand out into the holy precinct through the open portico. By means of the temple the God is present in the temple. This presence of the God is in itself the extension and the limitation of the precinct as a holy precinct. The temple and its precinct, however, do not fade away into the indefinite. It is the temple work that first fits together and at the same time gathers around itself the unity of those paths and relations in which birth and death, disaster and blessing, victory and disgrace, endurance and decline, acquire the shape of destiny for human beings (Gormley 1996b: 156).

Gormley wants to revive this notion of presence. But, he adds; 'Can we have presence without the God'? (Gormley 1996b: 156). Quoting this passage by Heidegger on rootedness and 'presence' can invoke the misunderstanding that Gormley has a similar 'presence' and rootedness in mind as Heidegger, whose view played a role in a nationalistic rootedness of the German people during the Nazi period. Gormley views presence differently. In his sculptures of the body, he is looking for an image for the rootedness of the identity of the human being in his body and in the earth; a rootedness that crosses the boundaries of race, faith, and language (Gormley 1993: 140). I will show what he means by that via his work.

Land, Sea and Air II (1982) shows three human figures. The figures we see are not 'imitations' of the human figure, not representations but moulds of it. They are 'body cases', moulds of a human being made from fibreglass and lead. The use of lead here is not to give a certain meaning to the work as is the case with Anselm Kiefer. It is chosen, rather, for technical reasons and as 'insulator-against liquid or sound leakage, against radioactivity' (Gormley 2015: 18). The three figures are on the beach near the sea. One is sitting on his knees bowing deeply toward the earth, another is standing straight up, staring out over the sea, while the third is kneeling, looking up at the sky. Each figure presents a sense that fits a certain part of the 'elemental' world. The earth requires listening, thus the accent on the ears of the human being who is bowing deeply towards the earth. The figure staring out over the sea is looking with wide open eyes to the distant horizon. The one looking at the sky has his nostrils wide open in order to be able to breathe the air. He breathes air (pneuma) in and out through his nose. This 
work shows how much the human being as body is connected in different ways with the earth. In the kneeling and listening posture, the human being is connected with the earth, via his breathing with the sky, and standing straight up the human being is connected through his eyes with the space around him and the distant horizon.

Does the image of the person who is staring out over the sea express transcendence? The figure of a person with his/her back turned toward us staring out over the sea to the enormous sky is well known from Caspar David Friedrich's painting Monk by the Sea (1808-1809). The Lutheran Friedrich experienced the infinite as religious transcendence, as an expression of God the creator. In his sculpture A View, A Place (1985-1986) Gormley repeats the theme of a similar figure with his back turned towards us staring toward the distant horizon. We see the human figure standing upright on a hill, looking into the distance. Gormley, who was raised a Catholic, rejects any explanation of his work as portraying transcendence or a utopia (Gormley 1993: 132). The figure in Land, Sea and Air II who is staring out over the sea is, just like the other two figures, on its own. The figure in $A$ View, A Place is standing alone on the hill. Are we to think of a depiction of the loneliness of the contemporary human being, as Edvard Munch did in his Melancholy (1894)? No, it concerns the awareness of that which transcends oneself and that one is part of a wider consciousness. In that sense, there is transcendence of oneself. Gormley says: 'If Caspar David Friedrich's Monk by the Sea is a Rothko with a man in it, I am trying to make a case for a man containing the boundless space of consciousness' (Gormley 1992: 128).

\section{Buddhism Inspired Presence}

Gormley derives his view of sculptures and their meaning from Buddhism (Gormley 2015: 143). He thus breaks with the Western tradition of sculpture, as stated above. Traditional Western sculptures are often an expression of the status of the power or authority of a political or royal figure. We also have sculptures that express an action within the framework of a story-one could think here of the David (1501-1504) of Michelangelo, which depicts David as the hero who can defeat the giant Goliath. For Gormley, sculptures do not express an action but a being, a place: the presence of the body; the body as a place: 'With Buddhist and Jain Tirthankara sculptures the idea of the body as a place is conveyed' (Gormley 2015: 143). Gormley wants to express in his work what he experiences in his Buddhism inspired meditation, especially the continuity of the space of the consciousness with the space in general (Gormley 2015: 143-144).

It is in that sense that two of the figures of Land, Sea and Air II are to be understood: the one staring out over the sea and the other kneeling with his head lifted upwards to the sky, deliberately breathing in and out. 
'Pneuma' is not a state of action but a state of being, of concentration (Gormley 2015: 166). This concerns the human being becoming aware of being a body. 'The idea of being a place is rather like one consciousness being subsumed within a wider consciousness.' (Gormley 1993: 135). Gormley is interested in his sculptures of the human form not as mimesis, not as the representation of the body but, as stated, in the body as place and presence. He wants to re-invent the body anew 'from the inside, from the point of view of existence'. That is why he makes use of his own body as a mould for the sculptures (Gombrich 2000: 10). His Learning to See I (1991) also depicts that: here we see an upright figure with closed eyes, his hands held stiffly alongside his body, the body in a very conscious state. It is a plaster mould of Gormley's own body. It took an hour and a half to make the mould. He was able to stay in this position for that long because of his training in the Vipassana meditation technique in India (Hutchinson 2000: 34). In this technique, the attention is open and undetermined, unlike the case in a meditation technique in which one is focused on a specific point. Here it is a matter of observing, rather than one of judging or excluding; it is one of taking in and letting go again. Emotions and situations can be recognised as such in that way. One receives a clear, wide view, which leads to insight on how one should act (Nugteren 2015: 66-76).

Gormley's sculptures as moulds have an empty space within. In Gombrich's interview with him, Gormley says: 'What I'm doing is realizing, materializing ... the space within the body', which, he continues, is difficult to explain in language:'[I]t's to do with meditation' (Gombrich 2000: 10). He is interested in the space that the body is. What is the space one inhabits when one closes one's eyes? (Gormley 1993: 135). That is what the title of the work Learning to See I points to. It is an invitation for the viewer to use the work as a means for reflection and to become aware of the internal darkness of the body' (Gormley 2015: 166). A portrait of the famous Buddhist king of Cambodia, Jayavarman VII (1181-1218), can clarify what that means. In this portrait, his face is smiling and expresses an internalisation of observation. It shows the Buddhist teaching of compassion for all living beings and the idea of metta or friendliness. ${ }^{1}$ Gormley wants to express this internalisation of observation in his Learning to See I. He remarks here that this Buddhist portrait differs fundamentally from what he grew up with: Christ's body on the cross (Gormley 2015: 168). I will return to this remark below.

As with Learning to See I, Gormley constantly emphasises the role of the involved observer of his work. His Allotment (1996) was made in collaborauniversal love or loving kindness is experienced. 
tion with the local public and involves angular body cases in which it also concerns physical presence in relation to physical space. They are empty, and Gormley asks the viewer 'to fill the empty spaces with his of her own bodily experiences' (Gormley 1996a: 151).

To return to Land, Sea and Air II: How are we to understand the figure bowing, listening with his ear to the ground? A statement by Gormley can point the way: 'We are earth above ground, clothed by space, seen by light' (Gormley 1989: 124). The figure kneeling on the ground is aware of his connectedness with the earth. He explores this more in Close I (1992) and in Close IV (1992) where someone is lying flat on the ground with arms and legs spread as if he wants to be attached to the ground. These sculptures show that the human being needs a fixed place in the earth, but at the same time that place is not that fixed because we are subjected to the forces of nature, to gravity and centrifugal forces. Our rootedness in the earth belongs to the human condition, but this rootedness is precarious because of these forces of nature. Close $I V$ materialises this uncertainty and points to the point of contact between awareness and matter (Gormley 1993: 132; Gormley 2000: 24).

In short, viewed in connection with other works by Gormley, Land, Sea and Air II is intended to show presence to the viewer, the body as presence. This concerns an attitude of quiet concentration and awareness in connection with the 'elemental' world (Gormley 2015: 168). That is a presence 'without the God', which is very different from Heidegger's aanwesen in which presence (aanwesen) has nationalistic features. It is also a different presence than what Sutherland's Christ in Glory is intended to show, as we will see.

\section{Presence in Sutherland's Christ in Glory}

If the God of the Bible does exist, then his hidden presence in the world and among people is characteristic of him. In art that comes out of the Christian tradition, God becoming present is important. That obtains not only for Eastern Orthodox icons but can also be seen in Western works (of art) where it concerns the imaging of creation, of the renewal of life and the completion of the world (Stoker 2019: 244-267). I will limit myself here to one example of this: Graham Sutherland's Christ in Glory (1951-1962). Sutherland (1903-1980) was one of the most preeminent English artists of the previous century. He was the official artist of the war from 1940-1945 and was inspired in his work generally by, among other things, the landscape and religion (Alley 1982).

When one enters the Anglican Cathedral of Coventry, which was rebuilt after the Second World War, the enormous tapestry, Christ in Glory in the Tetramorph, can be seen on the high wall on the east side of the cathedral, 
behind the high altar. It is 22.76 metres high and 11.58 metres wide. It is a full-body portrait of Christ, surrounded completely by an oval shape, a mandorla; the hands and feet show the red signs of the wounds of the crucifixion. He looks gently and at the same time exaltedly into the cathedral.

The large Christ figure and the colours of the tapestry draw the visitor's attention immediately upon entering the church: the off-white of Christ's robe, the grey tints in the yellow mandorla; the yellow that is repeated in the great rectangle on the work and in the frames of the Four Evangelists and especially the green outside the mandorla. Just as the archbishop of Canterbury, Rowan Williams, said at the jubilee service on 25 May 2012: 'The first thing this building teaches us is to see Jesus' (Journey 2014: 19). Christ is seen from every corner of the church.

Christ in Glory is a twentieth-century 'sacred portrait' of Jesus that goes back to the Western Christ in Majesty. Sutherland was confronted with the challenge of translating what was a living image for the Middle Ages into one for the secular society of the twentieth century (Révai 1964: 13, 16, 77, $80)$.

The tapestry is a free rendition of the vision from the Revelation of John. The complete title is Christ in Glory in the Tetramorph and thus points to the symbolic ranking of four elements: according to the biblical book of the Revelation of John, chapter 4, John saw four creatures (animals) in front of and surrounding the throne in the heaven. Sutherland takes the four traditional figures as his starting point but reproduces them in a lifelike way. On the upper left, we see a human figure, Matthew, as if he is stepping out of a window and looking at Christ. On the upper right is the eagle (John), on the lower left the ox (Luke), and on the lower right the lion (Mark). Sutherland portrays the animals in their uniqueness as symbols of creation. Christ is thus surrounded by creation, by man and animal.

Sutherland depicts Christ as the God-man, in line with church tradition, a figure with great vitality, the priest who raises his hands during the Eucharist, with his arms held close to the body to emphasise the power of the host. In addition to portraying the humanness of Christ, Sutherland also wanted to portray a feeling of power in his Christ figure insofar as Christ is also God (Révai 1964: 27). He was not looking for a depiction of a wise man but a being that-as the Word that became flesh and by whom everything was made (John 1)—created everything by his powerful hand.

With respect to style, Sutherland's portrayal of Christ's face with a beard has a close affinity with the style of Byzantine icons. The composition has a hieratic quality: the Christ figure is positioned facing front, it is symmetrical and rectangular, but this symmetry is broken by the oval mandorla.

The atmosphere of the inside of the church-whose baptismal font is made from a rock from Bethlehem, near the 'jubilant' colourful glass win- 
dow, and the Christ in Glory that covers the whole back wall—can lead to the experience of that as a place of the appearance of the Invisible in the visible.

\section{The Presence of Christ}

How can the visitor to the Cathedral experience this work religiously? Does the work Christ in Glory portray Christ becoming present? I have described elsewhere how a work of art can be open for religious transcendence (Stoker 2019: 263-266). The hints the work gives and a disclosure experienced by the observer involved are important. The hints function as 'religionmaking characteristics': they point to the work of arts religious character. Here these hints are the work itself, the hieratic style of the tapestry and the title of the work: Christ in Glory. Even though these hints can be easily recognised here, that does not mean that people also experience the painting as religious. That requires a disclosure-one has to just 'see' it; the image 'speaks' to one. The viewer has the experience that his usual way of looking is interrupted and transformed.

For the involved observer, the invisible Christ can become present through a disclosure in the viewer's interaction with Christ in Glory. The tapestry thus functions here as an intermediary: it points to Christ. The viewer can experience the tapestry as if Christ is looking at him. It is like an icon. The French expert in theological images, Jean-Luc Marion, remarks: in the icon, the gaze moves along itself in the direction of an invisible gaze that looks at him from glory' (Marion 2004: 78). It can be an interaction whereby what Jesus said at the conclusion of Matthew can speak to the visitor through the tapestry: 'All authority in heaven and on earth has been given to me... And surely I am with you always, to the very end of the age' (28:1820). For the involved observer the invisible Christ can become present through interaction with Christ in Glory in the same way that Christ becomes present through prayer.

\section{A Comparison}

Works like Gormley's Land, Sea and Air II and Learning to See I and Sutherland's Christ in Glory show that presence in the visual arts is important but is viewed in different ways. But can different works of art be compared? In this case, the one artwork is a tapestry and the other a sculpture. Gormley's Land, Sea and Air II is an example of what people call an indexical sign, a sign that is physically connected with or is caused by its referent. The image here after all is the mould of a body of a human being. The mould emphasises the presence of the body. The parallel in the Christian tradition is the image as relic. Gormley himself points to the medieval reliquary St. Allards Foot (1331): it is both a mould and a container that contains the relics of the foot. It is precisely what is inside that is important, even though we do not 
see what that is (Hutchinson 2000: 47). As far as the art form is concerned, there is a correspondence between Land, Sea and Air II and Learning to See I with the Technological Reliquaries (1965-1967) of the Catholic artist Paul Thek (1933-1988). These are indexical images, not true relics but imitations, as is also the case in Gormley's work. Thek's Fishman, for example, is a mould of his own body. The image shows him with eyes closed, the body covered with fishes, and the hands above his head as if he is swimming. The fish refer to the biblical text 'I will make you fishers of men' (Matthew 4:19) and to the ichthys symbol of the early Christians. The fish keep the Fishman up in the air, Thek says. This points, in connection with the relic character of Fishman, to Thek's belief in the resurrection (Stoker 2019: 149-151).

The correspondence of Fishman to Gormley's work is that both emphasise the material character of the work. In both, the work of art is after all connected with its referent: it concerns a mould of the artist's own body. Presence here is connected directly with the work of art, the moulds of Thek's and Gormley's bodies. Using a different source of religious inspiration leads to a different kind of presence. Thek's work is symbolic and refers to biblical stories. Fishman expresses Thek's own belief in the resurrection, of his future presence with God. Gormley rejects that kind of belief on the basis of his own view that it is a question of presence in the image itself, of the body as a place without reference to the "certainties of symbolism [and] mythology' (Gombrich 2000: 28) such as the belief in the resurrection. Even though there is correspondence between Thek's and Gormley's work because of the relic character of their work, that does not affect the difference between them with respect to the view of presence. In the Christian tradition, the image is a 'passage' to what is depicted. That obtains also for the relic insofar as it is not magic. It has power because it is a copy or extract, physically connected with what it belongs to, Christ or a saint. Thek's Fishman does not refer to a saint or Christ, and, in this respect, it is a quasi-relic that expresses the hope of resurrection, a future presence of the human being with God.

In the image as 'portrait', like Christ in Glory, presence, Christ becoming presence, occurs via the image of what is depicted. The object of the veneration of the image is not the image itself but-according to Christian tradition (The Second Council of Nicea 787) —what is depicted. In the history of the Christian image, presence has to do with a relationship with the transcendent God or the exalted Christ. For Gormley, transcendence takes the form of radical immanence: the human being in relationship with both his inner space and external space, nature or other people. The placing of the figures of Land, Sea and Air II in the open space on the beach at the sea emphasises that. 
This is the background, theologically speaking, of the difference between Christ in Glory and Gormley's works: the Christian tradition views the human being as a creation of God. He or she lives in his or her presence only in dependence on God. What the theologian Ingolf Dalferth says obtains for everyone who is open to religious transcendence when viewing an image like Christ in Glory: 'I live in the present, and can become present to my present, because God become present to me, I begin to realise my infinite dignity and uniqueness of being singled-out by God ... a his singled out creature in the presence of my creator' ... 'I become aware of God's presence by becoming aware of how God becomes present to my presence' (Dalferth 2006: 29-30). For Gormley, it has to do with a presence without God the creator. The human being is present as body and awareness in a world in which everything is uncertain. Hutchinson describes Gormley's view of the human being as follows: '[W]e are embodied and conscious. Everything else is uncertain' (Hutchinson 2000: 65).

Gormley points, as we saw above, to the difference between the Catholic crucifix and the portrait of Jayavarman VII (1181-1218) whose face is smiling and expresses an internalisation of observation. That points to a difference in the view of and dealing with reality. The historical Gautama Buddha (Shakyamuni) (5th century BC) viewed reality as suffering-everything is suffering-from which people had to be rescued. Various forms of meditation are part of the path to deliverance from reality as suffering. In later Mahayana Buddhism, Nagarjuna (ca. 200) spoke of the emptiness of everything: all things are without being and substance; they are mere illusion, mere appearance. Reality is viewed as maya, as an illusion. Gormley himself calls the viewer to meditation and awareness of his presence as a body in an uncertain world. The human being can thus act very deliberately in life: 'We are embodied and conscious. Everything else is uncertain', as Hutchinson writes above Gormley's view of the human being.

There are questions that can be raised here about Gormley's view of the human being in relation to Buddhism and Christianity. Both religions reject the egoism of the empirical I. Just like Buddhism, Christianity also holds that the empirical I has to die in order to truly be alive (Luke 17:33; Galatians 2:20). Unlike Buddhism, however, Christianity grounds the true self in God (Küng 1988: 142-147). My question for Gormley is in what way, in his view, does the empirical I die in order to arrive at a renewal of life?

There is a difference between the Buddha, sitting on a lotus throne and smiling, striving for enlightenment and reaching Nirvana on the one hand, and the crucified Christ (Küng 1988: 63-69). In his Christ in Glory, Sutherland also shows Christ not only as Christ in glory but also as the wounded Christ. At the bottom of the tapestry, there is a crucifixion scene with the sun and the moon on both sides. That could be surprising because the 
theme is, after all, Christ in Glory and not the suffering Christ. About his choice for the crucifixion scene at the bottom of the tapestry, Sutherland himself says that he has enough reasons to include a tragic and sombre element to contrast with the rest. He did that against the background of the death camps of the Second World War and of all other violence in the twentieth century. There is the prospect of a world of peace and justice because of a wounded Christ (Halík 2018), the cross and resurrection.

\section{In Conclusion: Sound II in the Winchester Cathedral Crypt}

The different views regarding presence do not exclude Gormley's sculpture of a human figure from offering inspiration for the Christian religion. His Sound II (1986) is in the crypt of the Winchester Cathedral. It is a mould of a body, an upright figure but unlike the one in Learning to See I. Here the head is bowed and the hands form a bowl at heart height. A hole in the chest allows water to fall into the hands so that it can flow onward into the body and, conversely, if the body is full the water can flow back into the water in which the figure stands. In this context, it takes on the meaning of the baptism of Christ or the idea of Christ as the source of living water (Pattison 1998:182-185).

In this context, presence means the renewal of life through baptism. Sound II reminds the Christian tradition of something important. After all, Gormley is concerned with the renewal of life, but this renewal for him comes via meditation, via the awareness of the body as place, as presence. The sculpture of the crypt can make the involved observer understand that the renewal of life is not limited to the ritual of baptism but is also a matter of the renewal of the inner being of the human person. Sound II can lead him or her to look at the practice of meditation, which is a (somewhat neglected) part of Christian spirituality. Christian meditation is directed at the revival and strengthening of the desire for God. Mystics even strive for a certain union with God. Meditation can be meditation on a text, a spiritual reading of the Scripture (lectio divina). Sometimes, meditation can also be done using images (a personal devotional object) or a meditation with no image (Bras 2015: 9-21; Van Welie 2015: 23-33). Gormley's Sound II in the crypt of Winchester Cathedral points the involved observer to the importance of the renewal of life after baptism through meditation as an important part of Christian spirituality.

I pointed above to the shortage of attention, according to some, in our Western culture for presence. Gumbrecht emphasises the work of art in its materiality in reaction to placing too much accent on the meaning of a work of art. As we saw above, in his own work, inspired by Buddhism, Gormley gives expression to Gumbrecht's view of presence in art. The image itself is presence. We need to deal with it not through interpretation but in a medi- 
tative way. Marion points to the shortage of attention for the invisible in our reality and points to the icon as the presence of the holy as an alternative. Sutherland's Christ in Glory is an example of such a presence of the invisible Christ in art.

\section{Bibliography}

Alley R (1982) Graham Sutherland. London: Tate Gallery.

Bras K (2015) Van veelheid naar volheid. In Prins W \& Collard J (red) Meditatie. Heeswijk: Berne Media, pp 9-21.

Dalferth IU (2006) Becoming Present: An inquiry into the Christian sense of the presence of God. Leuven: Peeters.

Gombrich EH (2000) E. H. Gombrich in conversation with Antony Gormley. In Hutchinson J (ed) Antony Gormley. New York: Phaidon Press, pp. 8-29.

Gormley A (1987) Concerning the Religious Dimension in My Art. In Hutchinson J (ed) Antony Gormley. New York: Phaidon Press, p. 120.

Gormley (1989) Being the World. In Hutchinson J (ed) Antony Gormley. New York: Phaidon Press, p. 124.

Gormley A (1992) Learning to See: Body and Soul. In Hutchinson J (ed) Antony Gormley. New York: Phaidon Press, p. 128.

Gormley A (1993) Interview met D. McGonagle. In Hutchinson J (ed) Antony Gormley. New York: Phaidon Press, pp. 130-143.

Gormley A (1996a) Allotment: Interview with Hans Anderson. In Hutchinson J (ed) Antony Gormley. New York: Phaidon Press, p. 148-151.

Gormley A (1996b) Still Moving. In Hutchinson J (ed) Antony Gormley. New York: Phaidon Press, pp. 154-156.

Gormley A (2015) Holborn M (ed) On Sculpture. London: Thames and Hudson.

Gumbrecht HU (2004) Production of Presence: What meaning cannot convey. Stanford: Stanford University Press

Halík T (2018) Raak de wonden aan: over het niet zien en toch geloven. Utrecht: KokBoekencentrum Uitgevers.

Hutchinson J (2000) Return (The Turning Point). In Hutchinson J (ed) Antony Gormley. New York: Phaidon Press, pp. 32-95.

*** (2014) Journey into the Light: The Art Treasures of Coventry Cathedral. Their Making and Meaning. Uitgave Coventry Cathedral.

Kaiser CV (2013) Anish Kapoor: Le Spirituel dans l'Art. Rennes: Presses universitaires de Rennes.

Küng H \& Bechert H (1988) Christentum und Weltreligionen: Buddhismus. München: Piper. 
Marion J-L (2004) The Crossing of the Visible. Stanford: Stanford University Press.

Nugteren A (2015) Over de zin van meditatie. In Prins W \& Collard J (red) Meditatie. Heeswijk: Berne Media, pp. 66-76.

Pattison G (1998) Art, Modernity, and Faith. London: SCM Press.

Révai A, ed (1964) Sutherland, Christ in Glory in the Tetramorph: The Genesis of the Great Tapestry in Coventry Cathedral. London: The Pallas Gallery.

Stoker W (2019) God opnieuw verbeeld: een theologische kunstbeschouwing. Almere: Parthenon.

Van Welie W (2015) Meditatie in beeld in de late Middeleeuwen. In Prins W \& Collard J (red) Meditatie. Heeswijk: Berne Media, pp. 23-33. 